\title{
Collaboration with teachers in the domain of school counseling ${ }^{1}$
}

\author{
Slađana Zuković ${ }^{1}$, Senka Slijepčeviće, \\ ${ }^{1,2}$ University of Novi Sad, Faculty of Philosophy, Department of Pedagogy, Republic of Serbia
}

\begin{abstract}
.
The paper starts from the point of view on the necessity of integrative and system based approach to school counseling which, among other things, requires active collaboration with teachers. In that sense, the objective of this research was aimed at examining the experiences of pedagogues in the domain of their counseling practice in the school setting in Serbia. More specifically, we are interested in experiences which pedagogues have in the area of collaboration with teachers regarding counseling practices. Pragmatist qualitative research approach was used in this research with the semi-structured interview as a research technique. There were 81 elementary school pedagogues that were participating in this research. The results show that majority of teachers are open for collaboration with pedagogues during school counseling, especially in cases when students experience learning difficulties or when there are disciplinary issues in classes. Teachers' acceptance of pedagogues' advice is dependent on their personality and their classroom management style. Interestingly, results also show that teachers at lower levels of education are more open for cooperation. Based on the results of this research we discuss the possibilities for improving the practice of collaboration with teachers in the domain of school counseling. In conclusion this paper offers recommendations for improving the partnership relations as a basis for effective counseling with students.
\end{abstract}

Keywords: Collaboration, counseling, partnership, pedagogue.

\section{Introduction}

The philosophy of the school counseling is based on the ecosystem theory of personality development, which implies that it is necessary to tend to the conditions and context of child's development in order to adequately influence physical and psychological development of a child. General school climate, current school policies, as well as an understanding of the school's role in student development (school doctrines and conceptions) has the crucial influence on the overall organization and content of school counseling. This means that school counseling should be understood as the process that follows behind the set of different program-designed educational activities, i.e. the process that permeates all spheres of educational work (Resman, 2000; Zuković, 2017). In this regard, school counseling requires a

1 This paper was written within the project "Quality of educational system of Serbia in the European perspective" (179010) and "Digital media technology and socio-educational changes" (47020) financed by the Ministry of Education, Science and Technological Development of the Republic of Serbia. 
collaborative relationship between all members of the school staff, family and the wider community (Mavroskufis, 2013; Zuković, 2013), and involves teamwork in which the knowledge, skills and abilities of employees are combined in a cooperative way (Kostović \& Oljača, 2012). In fact, teamwork, based on collegiality, enriches everyone who participates in it, creates opportunities for learning and information exchange, and enables illumination of the problem and analysis of specific situations from a number of different professional fields and points of view (Reardon, 1998). Therefore, in order to maximize the effects of school counseling, it is necessary to achieve participatory action by all subjects in a particular school context, which implies their close cooperation and supportive relationship (Zuković, 2017).

The key role in this process is played by school counselors, who, in addition to professional competencies for counseling, have also developed competencies for the development of pedagogical relationships with students, parents and colleagues, which are necessary for counseling to truly be a helping and understanding relationship (Jul \& Jensen, 2014; Juul, 2013). However, the thing that often obstructs the role of a school counselor is the dilemma of whether school counseling should be focused on so-called personal counseling, aimed primarily at the development of a student / individual or group of students, or it should be directed towards the development of the school as an institution. The answer to this question should be sought in the integration of these two segments, which means that school counseling should be a synthesis of direct counseling with students and working to create conditions for improving all segments of the educational process in the school. To achieve this, the school counseling service must be open not only to students but also to teachers, parents and school leadership (Zuković, 2016). Such an approach allows the development of collaborative, partnership-based relationships based on a sense of trust but also shared responsibility in the counseling process (Vernon \& Kottman, 2009).

The literature (Resman, 2000) points out that school counseling is made up of three processes that are very often intertwined:

- Direct counseling with students is an activity that the school counselor perform with individual students, smaller groups of students, or with the entire class. It also includes any kind of problem-solving assistance where students directly address the counselor regarding their school work (learning), and various personal and social problems. The aim of this process is to enable students to independantly deal with problems and overcome certain obstacles. At the heart of the counselor's role is knowledge of human development and personality, intra- and interpersonal relationships, decision-making and problem-solving processes, leading the counseling process in individual and group form, and in particular, establishing trust.

- Consulting is the collaboration of the school counselors with the "third party", ie. with parents, teachers, school leaders and others who hold child's interest at first hand. These are all persons who directly or indirectly influence the students and who are important to their progress and development. In this role, the counselor is continuously consulting and helping them during problem solving process and in seeking the answers on how to successfully work with individuals or a group of students. He/she is assisting them in acquiring knowledge, individual skills and abilities, getting to know the child/student, objectively evaluating the work of an individual or entire class, guiding the learning process, raising self-awareness and confidence, and an optimistic view on educational process. 
- Coordinating is the process in which the school counselor takes the initiative and incentive in organizing and leading individual activities. It is most often about programs that are related to the growth, development, life and work of an individual or group of students. In this type of action, which is based on the view that adequate personality development involves changing and adjusting the social environment, the role of counselors as initiators of change is emphasized. The counselor is expected to take leadership role in different teams and initiate the implementation of various projects and educational programs for teachers and parents. Coordination, however, is not limited to programs and activities within the school, but also to activities (for example, enrollment of children in first grade, professional counseling, etc.) that require cooperation and closer linking of the school with other institutions and the local community (Resman, 2000: 60-61).

These processes imply the view that the counseling program should be an integral part of the school curriculum, starting with the needs of the school as a whole, as well as the needs of all subjects of school life individually. However, the fact is that school counseling is a very broad area of activity for which there is no well-defined work program, but is mainly based on general theoretical concepts and guidelines on effective and efficient counseling. This situation often results in different practices, which may be effective by themselves, but which sometimes do not fit into the contemporary concept of school development. Thus, for example, the "traditional ethos of school counseling" is often present in schools, that is, an individual model of counseling based on the concept that a particular problem "resides within the individual" (Bor et al., 2002). The application of such a model causes the individual (most often the student) to be the focus of the counseling work without paying enough attention to the importance of involving significant others. Also, situating the problem within the individual does not provide sufficient opportunities to reflect the effects of counseling work on improving the educational work and school climate.

It is important to note that one of the difficulties in achieving the goals of school counseling may also be placed in the wrong or inadequately formed beliefs of teaching staff about the purposes of counseling. Specifically, teachers sometimes perceive counseling as negative, considering that students use it as a way to get out of the classroom and avoid some teaching activities. On the other hand, there is a phenomenon that teachers expect the school counseling service to solve any problems that they themselves have in establishing relationships with students (especially when it comes to discipline in class). Such beliefs can prevent the establishing of collaborative relationship between counseling and teaching staff, which is why it is important to educate teachers about what counseling is and why it should include collaboration and joint action (Vernon \& Kottman, 2009; Zuković, 2016).

That is why it is increasingly striving for a model that is characterized by the "ethos of systemic school counseling". It is an integrative model in which a particular problem is viewed as part of a broader context, and in which counseling is directed to the system as a whole, to relationships in a particular system environment. This practice involves the collaboration of the school counselor with various subjects of school life (students, teachers, school administration, parents). Thus, an individual's problem is related to others who are associated with the counselee (Bor et al., 2002). This does not mean that all these individuals will be involved in the counseling process, but during counseling their influence on the counselee will be considered. The point is that counseling is situated above the obvious problem - a broader social context is considered, which requires application of the ecosystem 
approach. This approach, based on the principle of circular causality, suggests that child / student behavior and development should be viewed through the interrelations and dynamics of at least three systems (e.g. child / student, family, school) (Bor et al., 2002; S. Zuković, 2012). The application of such framework helps to gain understanding of relationships on different levels (family-school, school-student, family-child) that could potentially be a source of a problem, and to guide counseling and specific interventions towards affecting multiple levels. This approach is especially important at times when unexpected, incidental events or certain traumatic situations occur at school. In such situations, an adequate reaction of all the members of school staff is very important, which especially applies to teachers who have direct contact with students on daily basis. Since teachers represent significant individuals in student's lives they are expected to be the initiatiors of different preventative and interventional activities. Although the fact that working on changing student behavior generally requires a change in teacher behavior, it is often the case that teachers show resistance to active involvement in the counseling process. That is why it is very important to get teachers to cooperate and to show them the importance of their role in the process of counseling with students (Chan, 2000; Vernon \& Kottman, 2009).

\section{Research objectives}

Although school counseling should strive for an integrative model that aims to support students at several levels, counseling practice often comes down to discussions between counselors and students. The involvement of other relevant subjects from the student's immediate environment has the aim of providing multi-level support, however it is still not sufficiently present in practice. Accordingly, a draft of this research was developed to examine the practical experiences of school counselors on the frequency and quality of collaboration with teachers in the field of counseling. On this basis, the following research tasks were set:

1. To what extent and in which situations school counselors involve teachers in the process of counseling with students?

2. What is the school counselor's opinion about the teacher's openness to cooperation and willingness to accept potential suggestions?

\section{Method}

The application of pragmatist qualitative research as a phenomenological approach aimed at gaining to understanding the phenomena under examination, as well as to looking at the respondents' self-perception about their own practice (Eatough \& Smith, 2008; Savin-Baden $\&$ Major, 2012). The data used in this research was collected using a semi-structured interview. The questions in the created Interviewing Protocol were formulated in advance in a way that ensures that the interview flow follows the assigned research tasks, but at the same time leaves room for the respondents to express their opinions freely. The respondents were asked the following questions: Do you and in what cases involve teachers in counselling process? How open are teachers to collaboration? How willing are the teachers to accept your suggestions regarding their relationship with the students (in cases where there is a problem between the teacher and the student)? 


\section{AREIL}

$2^{\text {nd }}$ International conference on Advanced

The sample consisted of 81 primary school educators (47 pedagogues ${ }^{2}$ from urban/suburban schools and 34 pedagogues from rural schools) from Vojvodina, Serbia. It was a convenient sample considering that the research was conducted in schools where final year students of Pedagogy studies have their internship done. The final year students of pedagogy had the role of assistant researchers. After a thorough preparation during which students received guidance on a professional approach to research and interviewing, they had the opportunity to talk with mentors/pedagogues about their school counseling practice. Data collection took place from 2015 to 2018, and interviews were conducted at the time of student internship. In this way, students had the opportunity to become familiar with the practice of counseling work at school, which was otherwise prevented due to the necessary protection of the data of counselees. Before starting the interview, the interviewees were informed about the purpose of the interview, the ethical standards of the research regarding the confidentiality of the findings and the voluntariness to participate in the interview. The duration of the interview itself was not limited given that the assistant researchers were taking the interview notes and the average interview duration was approximately 45 minutes. Respondents were given the opportunity to look at the veracity of the note and, if they deemed it necessary, supplement some parts.

The data obtained from the research were processed using qualitative thematic analysis (Braun \& Clarke, 2006) which included: familiarizing with the material, generating initial codes, identifying topics and subtopics, recoding data and refining topics, final defining and naming of the topics, drafting reports (final analysis and interpretation, backed by some of the original responses as a contribution to the description of topics).

\section{Research results}

Involvement of teachers in the counseling process. When asked whether the respondents involved teachers in counseling with students and in what situations a wide range of answers was obtained. Most respondents point out that teachers are often part of the counseling with students and that the best interests of the student themselves are always the focus when engaging in this process. School counselors also pointed out that each counseling situation is specific and that whether the teacher will be involved and at what stage of the counseling work depends on the situation itself. With a goal of greater transparency of the data obtained, Table 4 presents answers to the questions of how often and in which cases teachers are involved in the student counseling process.

${ }^{2}$ Pedagogue and psychologist are the most frequently employed school counselors in schools in Serbia. Pedagogues are experts whose area of work and responsibilities are generally similar to those of a school counselor in the Anglo-Saxon area. 
Tabela 4. Involvement of teachers in the counseling process.

\begin{tabular}{|l|l|l|l|}
\hline $\begin{array}{l}\text { Do you involve teachers in } \\
\text { counseling process? }\end{array}$ & f & In which cases do you involve teachers in counseling process? \\
\hline Yes, always & 25 & $\begin{array}{l}\text { - when they are class teachers } \\
\text { - when I need information about the student from the teacher } \\
\text { - always, except in cases that require discretion }\end{array}$ \\
\hline Yes & $\begin{array}{l}\text { - counseling regarding conducting lessons } \\
- \text { learning difficulties } \\
\text { - the need for intensive pedagogical work with certain students } \\
\text { or entire class } \\
\text { - when they are teacher trainees }\end{array}$ \\
\hline It depends on the situation & 24 & $\begin{array}{l}\text { - problems between student(s) and teacher } \\
- \text { problematic behavior and/or learning difficulties }\end{array}$ \\
\hline Rarely & 10 & $\begin{array}{l}\text { - complaints on teacher's performance } \\
- \text { planning and conducting workshops within group counseling } \\
\text { - working with students with disabilities }\end{array}$ \\
\hline
\end{tabular}

In addition to the questions about the frequency of collaboration with teachers in the field of student advisory work, the interview was deepened through the question about teachers' openness to cooperation and willingness to accept the educators' suggestions. Almost all respondents said that teachers are ready to cooperate always or in most cases, while some pedagogues pointed out that teachers are initially less open, but that "after a couple of conversations the situation changes". An interesting observation was made by several respondents who claim that lower grade teachers are more willing to cooperate than teachers that teach in higher grades. Despite the fact that almost all the respondents indicated the teachers' willingness to cooperate, there were several factors that determined whether they were really ready to accept the educator's suggestion:

1. Teachers' personality. Specifically, according to the respondents, the authoritarian type of teacher tends to accept suggestion with more difficulty. (e.g.: "A teacher with an authoritarian upbringing style will often, despite my suggestions, still come from a position of power, criticizing and condemning while not giving adequate support to the child".). Some respondents stated that the willingness of a teacher to accept what is suggested also depends on his/her vanity, and that some teachers are even offended if counselors suggest something to them. (e.g.:"Some will accept the suggestion without issue, and some will even be offended when you try to suggest something to them."). 
2. Teachers' professional orientation. More specifically, respondents point out that teachers from lower grades, teachers of social groups of subjects, as well as teachers at the beginning of their career are more willing to accept made suggestions. Particularly interesting is the statement of one respondent who points out the following: "In my experience, there is a big difference in the pedagogical preparedness of lower grade teachers and subject teachers. The former quickly understand the proposed measures and implement the plan more successfully. Since they work with students in all classes during the entire school day, they know them much better".

3. The pedagogues' skills as a counselor and the content of the suggestions they make. According to the respondents, "suggestions and advice must be precise and concise without unnecessary words, professional", focused on actions and not on personality, and related to a specific problem. Some respondents pointed out that the influence of school counselor also depends on their position and experience, and one educator stated the following: "Approach to every teacher is different, that way I try to win them over for establishing collaboration."

4. Lack of teacher's perseverance in honoring the agreement. A group of respondents indicated that the teachers readily accepted the suggestions, but that the realization of what was agreed upon was not always respected. The reasons for the lack of persistence in the implementation of what is agreed range from the fact that teachers do not recognize the problem, implement the agreement "to the extent suitable to them" or "don't understand the essence, they are putting in the effort but they do not have the capacity to carry it out appropriately".

\section{Discussion}

Contemporary aspirations in pedagogical science are aimed at emphasizing the importance of establishing partnerships between all stakeholders relevant to the education, upbringing and overall development of the child's personality. Partnership in education is a concept based on the assumption that different subjects of school life participate in decision making and taking activities towards creating optimal conditions for education, learning and development of the child (Pavlović Breneselović, 2010). Given the many benefits of counsellor's collaboration with different subjects significant for a child during the counseling process, it seems important to examine the actual representation and quality of this collaboration. The results of this research show that most of the respondents involve teachers in counseling work, but that the intensity of their involvement varies depending on the teacher's role and the specific nature of the situation at hand. Teachers who serve as a class teachers are often an indispensable part of counselling with students. Given that it is important to collect as much relevant information about the student as possible in order to carry out the advisory work effectively (Zuković, 2017), class teachers, as a person who collaborate with students the most, represent a very valuable asset to the counsellor. Other than that, teachers are involved in the counseling process in cases where there is a specific problem between them and the student(s). Earlier research has shown that the implementation of a comprehensive school 
counseling program, related to multisystemic guidance in counseling, which implies that the counselor must know and respect the various interconnected student-related subsystems (Keys \& Bemak, 1997), can have a positive effect on academic achievement of the student (Sink, 2003). According to some authors (Dixon et al., 2008), the benefits of collaboration between counselors and teachers can: increase teacher competencies in working with students from vulnerable groups, strengthen the connection between relevant subjects in the school environment, support parental involvement in school life and maximize use of limited school resources. Accordingly, close collaboration with the subjects of school life who have the most intense contacts with the student involved in the counseling can possibly increase the quality of the counselling itself.

Respondents noted that teachers' openness to accepting suggestions from counselors depends on several factors. As the most frequent response, the respondents stated that openness is highly dependent on the teacher's personality. Some respondents pointed out that in this domain the greatest obstacle to successful cooperation and acceptance of constructive criticism is teachers' vanity. However, the role of the pedagogue as a school counselor is crucial and unique in the process of promoting and facilitating collaboration between all participants of school life (American School Counselor Association, 2012), and these professionals serve as a "bridge" between all those participants (Bryan \& Henry, 2012). Therefore, counselors are expected to utilize their competencies in order to win the cooperation of those individuals in the school who initially refuse to do so. It is interesting to note the respondents that teachers that teach social sciences and teachers in lower grades of elementary school are more open to cooperation than teachers of the natural science group of subjects. A potential explanation for this research finding may lie in the characteristics of initial preparation of teachers in Serbia. Since there are no special faculties for teacher education (except in the case of teacher for lower grades of elementary school), the preparation of individuals for the profession of teacher differs significantly in the faculties of social sciences and those of natural sciences. The teachers who teach social science courses in their initial education take several courses in the fields of pedagogical, psychological and didactic groups of subjects, which largely prepares them for their future teaching role. On the other hand, teachers of natural science group of subjects are often educated to work in the industry and when they shift to the teaching profession for various reasons, they lack the adequate preparation to perform all teaching roles. In conclusion, by analyzing stated experiences of pedagogues, the need for a better and more systematic pedagogical and psychological education of the teaching staff is highlighted, especially when it comes to teachers of natural groups of subjects.

\section{Conclusion}

School counseling should not be a short-term process focused solely on a particular problem and current situation, but should be directed much more broadly - to the development of students and their preparation for proper functioning in new and different developmental environments, but also to the development of the school as a whole (Krstić \& Zuković, 2017; Zuković, 2017). It is therefore very important to bear in mind that the maximum effects of school counseling work are not possible without adequate and continuous cooperation of the school counselor with all subjects in the school life, and above all teachers. Specifically, promoting teamwork with teachers allows for a higher level of commitment to achieve set 
goals and make shared decisions, create a climate of support, understanding and trust, as well as develop a sense of belonging to the institution (Kostović \& Oljača, 2012).

Also, it is important to emphasize that, in accordance with contemporary paradigms in education (humanization and democratization, support of free initiative, application of different pedagogical ideas and concepts, transactional learning, collaboration, participation, action research of practice, reflexive practice) (Zuković, 2017) the role of the school counselor should be focused on helping the teacher know how to work, and not what to do. In line with this approach, knowing the implicit beliefs of teachers and accepting the role of "critical friend" is a good way for the counselor to work effectively with teaching staff. That way the counselor helps his or her colleagues become "reflexive practitioners", but also to overcome certain situations that can lead to "professional combustion" syndrome, which is often present among professionals working in schools (Domović \& Jurčec, 2010; Martinko, 2010).

All the above points to the importance of developing an integrative model, i.e. an ethos of system counseling (Bor et al., 2002). The application of it allows school counseling to become a dynamic process that focuses on patterns of behavior, relationships and feelings, in a way that allows certain problems or difficulties to be put into a new framework, which will lead to overcoming them. This can enable empowerment of the individuals, groups or the school as a whole to adequately address potential problems in the future.

\section{Acknowledgment (TNR 12pt. bold)}

This paper is an output of the science projects 'Quality of educational system of Serbia in the European perspective' (179010) and 'Digital media technology and socio-educational changes' (47020), financed by the Ministry of Education, Science and Technological Development of the Republic of Serbia.

\section{References (TNR 14pt., bold)}

[1] American School Counselor Association. (2012). ASCA national model: A framework for school counseling programs. American School Counselor Association.

[2] Bor, R., Ebner-Landy, J., Gill, S., \& Brace, C. (2002). Counselling in schools. SAGE.

[3] Braun, V., \& Clarke, V. (2006). Using thematic analysis in psychology. Qualitative Research in Psychology, 3(2), 77-101.

[4] Bryan, J., \& Henry, L. (2012). A Model for Building School-Family-Community Partnerships: Principles and Process. Journal of Counseling \& Development, 90(4), 408420. https://doi.org/10.1002/j.1556-6676.2012.00052.x

[5] Chan, D. W. (2000). Brief Intervention for School Problems: A Practical Approach for Hong Kong Teachers. Asian Journal of Counselling, 7(1), 65-83.

[6] Dixon, A. L., DeVoss, J. A., \& Davis, E. S. (2008). Strengthening Links between the Levels: School Counselor Collaboration for Successful Student Transitions. Journal of School Counseling, 6(21), 1-33.

[7] Eatough, V., \& Smith, J. A. (2008). Interpretative Phenomenological Analysis. In C. Willig \& W. S. Rogers (Eds.), The SAGE Handbook of Qualitative Research in Psychology (pp. 179-194). SAGE Publications Ltd. https://doi.org/10.4135/9781526405555.n12 


\section{AREIL}

$2^{\text {nd }}$ International conference on Advanced

[8] Jul, J., \& Jensen, H. (2014). Kompetencija u pedagoškim odnosima. Od poslušnosti do odgovornosti. Eduka.

[9] Juul, J. (2013). Škola u infarktnom stanju: Što učiniti kako bi djeci, roditeljima $i$ nastavnicima bilo bolje. Znanje.

[10] Keys, S. G., \& Bemak, F. (1997). School-Family-Community Linked Services: A School Counseling Role for Changing Times. The School Counselor, 44(4), 255-263.

[11] Kostović, S., \& Oljača, M. (2012). Pedagog i pedagoške dimenzije menadžmenta. Filozofski fakultet.

[12] Mavroskufis, D. K. (2013). Okruženje za učenje. In L. W. Anderson (Ed.), Nastava orijentisana na učenje - za nastavnike usmerene na postignuća (pp. 51-70). CDRSEE.

[13] Pavlović Breneselović, D. (2010). Partnerstvo u obrazovanju. Andragoške Studije, 2, $123-139$.

[14] Reardon, K. K. (1998). Interpersonalna komunikacija: Gdje se misli susreću. Alinea.

[15] Resman, M. (2000). Savjetodavni rad u vrtiću i školi. Hrvatsko-pedagoško-književni zbor.

[16] Savin-Baden, M., \& Major, C. H. (2012). Qualitative research: The essential guide to theory and practice. Routledge.

[17] Sink, C. (2003). Improving Academic Achievement in Primary Students Through a Systemic Approach to Guidance and Counseling (Research Report No. 4; pp. 1-24). Washington School Research Center. https://www.umass.edu/schoolcounseling/uploads/WSRC.pdf

[18] Vernon, A., \& Kottman, T. (2009). Counseling theories. Practical applications with children and adolescents in school settings. Love Publishing Company.

[19] Zuković, S. (2012). Porodica kao sistem - funkcionalnost i resursi osnaživanja. Pedagoško društvo Vojvodine.

[20] Zuković, S. (2013). Partnerstvo porodice, škole i zajednice - teorijski i praktični aspekti. Godišnjak Filozofskog Fakulteta u Novom Sadu, 38(2), 55-68.

[21] Zuković, S. (2017). Savetodavni rad u institucijama vaspitanja i obrazovanja teorijski i praktični aspekti. Filozofski fakultet.

[22] Zuković, S. (2016). Karakteristike i ključni faktori efikasnog savetodavnog rada. Zbornik Odseka Za Pedagogiju, 25, 99-113. https://doi.org/10.19090/zop.2016.25.99-113 